\title{
Effects of probiotics and enzymes on growth performance and haematobiochemical parameters in broilers
}

\author{
M. S. Rahman, A. Mustari*, M. Salauddin and M. M. Rahman \\ Department of Physiology, Bangladesh Agricultural University, Mymensingh-2202, Bangladesh \\ *E-mail: afrinadvm@yahoo.com
}

\begin{abstract}
An study was conducted on "Cobb-500" broiler chicks to evaluate the effects of probiotics and enzymes supplementation on growth performance, haematological and biochemical parameters. A total of 20 , fourteen days old broiler chicks were divided randomly into four groups using five broiler chicks in each group. Group A was designated as control group was given only normal broiler ration and rest of the groups were fed probiotics and enzymes, [Group B (probiotic Microguard® @ $1 \mathrm{gm} / \mathrm{L}$ ), Group C (enzymes preparation Acmezyme* $1 \mathrm{gm} / \mathrm{L}$ ), Group $\mathrm{D}$ (Microguard* $\mathrm{g} 1 \mathrm{gm} / \mathrm{L}$ and Acmezyme @ $1 \mathrm{gm} / \mathrm{L})]$ with drinking water respectively from $1^{\text {St }}$ to $21^{\text {st }}$ day of study. It was observed that probiotics and enzymes supplementation enhanced the body growth rate. At the final day of experiment the body weight was significantly increased $(P<0.01)$ in the treated groups in comparison with that of control group. Total Erythrocyte Count (TEC), Hemoglobin (Hb) concentration, Packed Cell Volume (PCV) were significantly increased $(p<0.01)$ in treated groups than the control group. Erythrocyte Sedimentation Rate (ESR) and Serum alanine aminotransaminase $(A L T)$ levels were decreased significantly $(p<0.01)$ than the control group. The serum Serum aspertate aminotransaminase (AST) level was decreased significantly $(p<0.01)$ in all treated groups except group $D$ than the control group. It is suggests that the poultry farming may be benefited using probiotics and enzymes.
\end{abstract}

Keywords: Broiler, Growth, Hematological, Biochemical

\section{Introduction}

A number of feed additives like antibiotics, steroids, vitamin, minerals and other growth promoters are used to improve the performance of broiler growth. The excessive dependency on medications threatens the mankind in antibiotic resistance. However, it is also discouraged to use growth promoters because of their residual effect in boiler meat.

Probiotics are feed additives that contain live microorganisms and promote beneficial effects on the host of favoring the balance of the intestinal microbes (Fuller 1989). The probiotics include live bacteria, yeast, their metabolites and $\mathrm{pH}$ adjusters, which contribute to maintain balance in intestinal microflora (Islam at al., 2004). Probiotic microorganisms are responsible for the production of vitamin B complex and digestive enzymes for stimulation of intestinal immunity, increasing protection against toxins produced by pathogenic organisms. Probiotic act as a mono or mixed culture of living microorganisms which beneficially affect the host by improving the properties of the indigenous microflora.

Probiotic organisms help to improve the environment of the intestinal tract. It may also be defined as living microorganisms, which is given to animals assist in the establishment of an intestinal population which is beneficial to the animal and antagonistic to harmful microbes (Sinnons and Sainsbury, 2001). The probiotic feeding assists in preventing colonization of pathogens in the intestinal tract and in producing certain enzyme like substances (Lee et al., 2007). Probiotics are clamed to exert beneficial effects on live weight gain, feed consumption, feed conversation ratio and livability (Mohan et al., 1996).

The nutritive value of available feed stuffs such as wheat, maize, rice polish, til oil cake, soybean meal etc. in Bangladesh contain more indigestible part. (Jin et al. 2000).

Most of the feed ingredients contain some anti-nutritional factors and non- digested part which inhibit feed utilization. The ant-nutritive effect is manifested by depressed nutrient utilization accompanied by poor growth. This adverse effect can be overcome by supplementation of exogenous carbohydrase (xylanase) enzymes improve digestibility of starch, protein, fat and apparent metabolisable energy in broiler feed (Choct at al., 1995). 
Considering the above facts the study was under taken to fulfill the following objectives:

i. To study the effects of probiotics and enzymes supplementation on growth performance in broiler chicks.

ii. To study the effect of probiotics and enzymes supplementation on haematological parameters such as Total Erythrocyte Count (TEC), Packed Cell Volume (PCV), Haemoglobin (Hb) concentration, Erythrocyte Sedimentation Rate (ESR), Serum alanine aminotransaminase(ALT) and serum Serum aspertate aminotransaminase (AST).

\section{Materials and Methods}

The study was conducted in Hamidur Poultry Farm, Mahigani, Rangpur during the period from $9^{\text {th }}$ April to $6^{\text {th }}$ May.

\section{Experimental birds}

Day old chicks (strain Cobb-500) marketed by Nourish Poultry and Hachery Ltd., Bangladesh, were purchased from local market for this experiment. The chickens were allowed to take rest for 6 days for the adaptation. The chicken was supplied with normal diet and water.

\section{Experimental diets}

The commercial broiler ration, commercial enzymes (Achmezyme $囚$ ) and commercial probiotics (Microgulard®) were purchase from the local market.

Group-A : fed with commercial broiler ration and fresh drinking water.

Group-B : commercial probiotics (Microguard®) @ 1gm/L drinking water plus commercial broiler ration and fresh drinking water for 21 days.

Croup-C : commercial enzymes (Achmezyme®) @1gm/L drinking water plus commercial broiler ration and fresh drinking water for 21 days.

Group-D : commercial probiotics (Microguard $($ ) @ 1gm/L and enzymes (Achmezyme®) @1gm/L drinking water plus commercial broiler ration and fresh drinking water for 21 days.

Table 1. Composition of supplemented enzymes (Achmezyme®)

Each $100 \mathrm{gm}$ powder contains:

\begin{tabular}{|c|c|}
\hline Enzymes & Amount \\
\hline Cellulase & 20,000 IU \\
\hline Xylanas & $2,00,000$ IU \\
\hline Protease & 20 IU \\
\hline Amylase & 40,000 IU \\
\hline Phytase & 20 IU \\
\hline Pactinase & 1400 IU \\
\hline Invertase & 400 IU \\
\hline Hemicelulase & 500 IU \\
\hline Lipase & 20 IU \\
\hline a-galactosidase & 100 IU \\
\hline
\end{tabular}

(The ACME Laboratories Ltd.)

Table 2. Composition of supplemented probiotics (Microguard $\AA$ )

\section{Lactobacillus acidophilus \\ Lactobacillus bulgaricus \\ Lactobacillusplantarum \\ Streptococcus faecium \\ Bifidobacterium bifidus \\ Bacillus subtilis}

Total viable count 5000 billion spores (PRIME CARE)
Bacillus Licheniformis

Bacillus Megaterum

Bacillus Mesentricus

Bacillus polymyxa

Saccharomyces bourlrdii

Routine management procedures were followed during the whole study period. 


\section{Biosecurity and sanitation}

Proper hygienic and sanitation programs were followed. To prevent the outbreak of disease strict biosecurity was maintained. The following measures were taken to maintain the biosecurity:

- Visitors were not allowed to enter in the house.

- All equipments in the experimental house were kept clean.

- Dead birds were removed promptly.

\section{Blood collection}

For studying haematological and biochemical parameters blood was collected at the end of study. A number of sterile test tubes containing anticoagulant (4\% trisodium citrate solution) at a ratio of 1:10 were taken. Sequential killing was done and blood was collected from each group through slaughtering. The haematological studies were performed within two hours after collection. For biochemical studies blood 2$3 \mathrm{ml}$ was collected in the sterile glass test tube. The blood containing tubes were placed in slanting position at room temperature for 6 hours. The tubes were then incubated overnight in the refrigerator $\left(4^{\circ} \mathrm{C}\right)$. The serum samples were separated and centrifuged to get rid of unwanted blood cells where necessary.

Serum samples were stored at $-20^{\circ} \mathrm{C}$ for biochemical enzyme analysis. Analyses were done in a quickest possible time.

\section{Statistical analysis}

The recorded data were analyzed statistically between control and treated groups of broiler chicken by the student's test ('t' test).

\section{Results}

\section{Effects on the body weight}

Effects on body weight of different groups of broilers are presented at Table 3, Fig. 1. Body weight on day 14 of age ( $1^{\text {st }}$ day of study) was observed that the body weight in control group $A$ was $333 \pm 1.5$, in the treatment group $B$ was $338 \pm 0.9 \mathrm{gm}$, in group $C$ was $334 \pm 0.6 \mathrm{gm}$ and in group $D$ was $346 \pm 0.9 \mathrm{gm}$. The data were more or less similar and not statistically significant $(p>0.05)$. The highest body weight was recorded in group $\mathrm{D}$ and lowest in group $\mathrm{A}$ and $\mathrm{C}$.

Table 3. Effects of probiotics and enzymes on body weight (gm) (Mean $\pm S E)$ in broilers on $21^{\text {th }}$ day of experiment

\begin{tabular}{|l|c|c|c|c|}
\hline \multirow{2}{*}{ Groups } & \multicolumn{4}{|c|}{ Mean \pm SE (gm) } \\
\cline { 2 - 5 } & Pre treatment & \multicolumn{3}{|c|}{ Post treatment } \\
\cline { 2 - 5 } & $\begin{array}{c}1^{\text {st }} \text { day of } \\
\text { experiment }\end{array}$ & $\begin{array}{c}7^{\text {th }} \text { day of } \\
\text { experiment }\end{array}$ & $\begin{array}{c}14^{\text {th }} \text { day of } \\
\text { experiment }\end{array}$ & $\begin{array}{c}21^{\text {th }} \text { day of } \\
\text { experiment }\end{array}$ \\
\hline A (control) & $333 \pm 1.5$ & $656 \pm 0.7$ & $1141 \pm 3.6$ & $1413 \pm 0.7$ \\
\hline B (probiotics) & $338 \pm 0.9^{* *}$ & $679 \pm 1.3^{* *}$ & $1195 \pm 3.4^{* *}$ & $1584 \pm 1.2$ \\
\hline C (enzymes) & $334 \pm 0.6^{* *}$ & $665 \pm 4.4^{* *}$ & $1170 \pm 1.2^{* *}$ & $1528 \pm 2.1$ \\
\hline D (probiotics+Enzymes) & $346 \pm 0.9^{* *}$ & $700 \pm 2.2^{* *}$ & $1232 \pm 1.0^{* *}$ & $1686 \pm 1.3^{* *}$ \\
\hline Level of significant & ${ }^{* *}$ & ${ }^{* *}$ & ${ }^{* *}$ & $* *$ \\
\hline
\end{tabular}

** $=$ Significant at $1 \%(p<0.01)$ level of probability

On day $35\left(21^{\text {st }}\right.$ day of study) was observed that the body weight in control group A was $1413 \pm 0.7$, in the treatment group $B$ was $1584 \pm 1.2 \mathrm{gm}$, in group-C was $1528 \pm 2.1 \mathrm{gm}$ and in group-D was $1232 \pm 1.0 \mathrm{gm}$. All the data was statistically significant at $1 \%(P<0.01)$ level. The highest body weight was recorded in treated group $D$ and lowest in control group $A$. But among the treated groups the body weight of group $B$ and group $\mathrm{C}$ were close to the control group $\mathrm{D}$. 
Data cataloged on $7^{\text {th }}, 14^{\text {th }}$ and $21^{\text {st }}$ day of study shows that the weight increased significantly $(\mathrm{P}<0.01)$. The body weight increased slowly in the control group $A$ in respective days of study but rise in body weight was noticed in the treated groups $(B, C$ and $D)$ and it was highest in group $D$ in comparison with control group A. Although body weight on $1^{\text {st }}$ day was more or less similar, but a distinct fluctuation was observed with the advanced of age $\left(7^{\text {th }}, 14^{\text {th }}\right.$ and $21^{\text {st }}$ days) among different groups and it was always highest in group $D$ where combined probiotics and enzymes were supplemented group. The highest body weight recorded in the present finding in group $D$ indicates synergistic effect of combined treatments of probiotics and enzymes. This finding is indirectly supported by the above mentioned findings (Kabir et al. 2005; Mohan et al., 1996; Panda et al. 1999; Ahmed et al. 2004; Zulkifli et al. 2000; Kim et al. 1988). The effect of dietary supplementation of probiotic Lactobacillus significantly enhanced body weight in broilers (Panda et al. 2006). Increasing the growth performance of broiler chickens by supplementing their diets with exogenous enzymes can contribute to positive changes in gut health (Rosin et al. 2007).

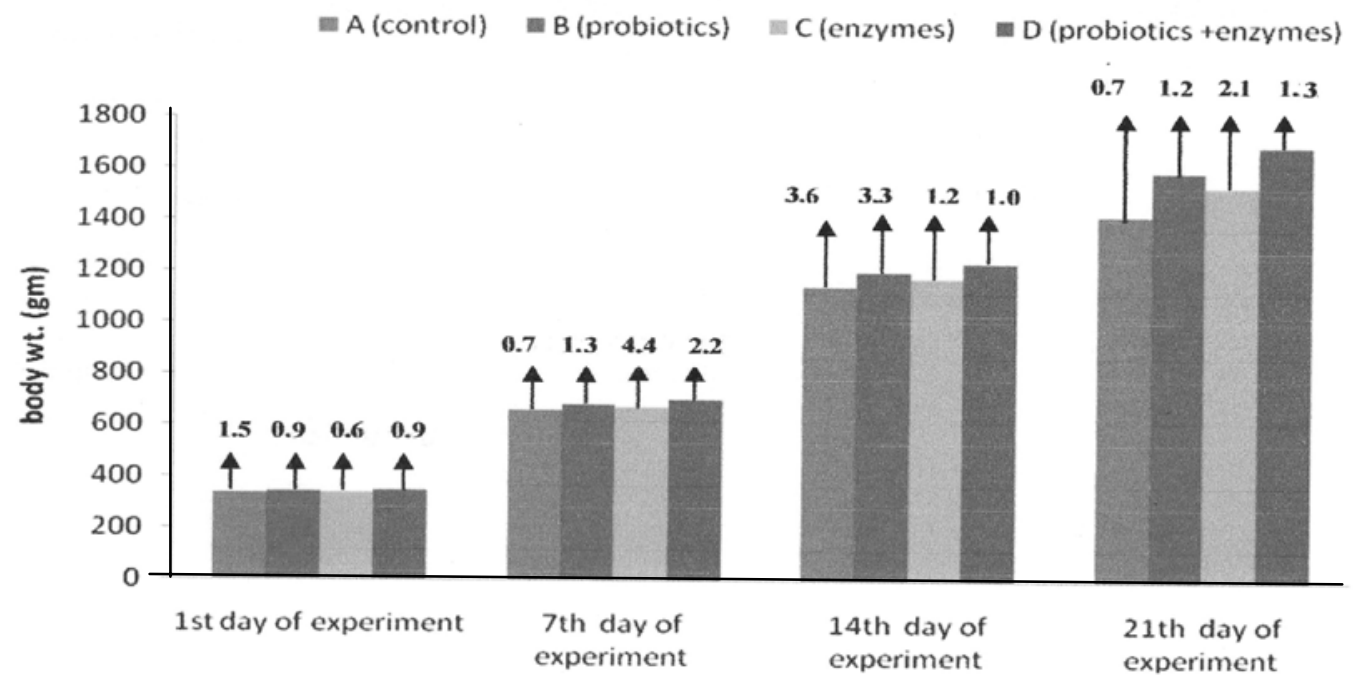

Fig. 1. Effects of probiotics and enzymes on body weight of different groups in broilers on $21^{\text {st }}$ day (mean $\pm \mathrm{SE}$ ). The superscript value above bar indicates standard error

\section{Effects on Haematological parameters}

Total Erythrocyte count (TEC million $/ \mathrm{mm}^{3}$ ): Total erythrocyte count in different groups of broilers is presented in Table 4 and Fig. 2. At $21^{\text {st }}$ day (35 days of age) the values of TEC in control group was $2.2 \pm 0.03$ million $/ \mathrm{mm}^{3}$ and in the treated group B was $2.7 \pm 0.01$ million $/ \mathrm{mm}^{3}$, Group C was $2.5 \pm 0.01$ million $/ \mathrm{mm}^{3}$ and Group $D$ was $2.9 \pm 0.03$ million $/ \mathrm{mm}^{3}$. The highest values of TEC in treated Group $D$ were $2.9 \pm 0.03 \mathrm{million} / \mathrm{mm}^{3}$ and lowest values in control group $A$ was $2.2 \pm 0.03 \mathrm{million} / \mathrm{mm}^{3}$. All the values of treated Groups were significantly $(p<0.01)$.

Table 4. Haematological parameters (Mean \pm SE) in broilers on $21^{\text {th }}$ day of study after treating with probiotics and enzymes

\begin{tabular}{|l|c|c|c|c|}
\hline Groups & $\begin{array}{c}\text { TEC } \\
\text { Millions/mm }\end{array}$ & Hb (gm/dl) & PCV (\%) & $\begin{array}{c}\text { ESR (mm in } \mathbf{1}^{\text {st }} \\
\text { hour }\end{array}$ \\
\hline A (control) & $2.2 \pm 0.03$ & $7.6 \pm 0.01$ & $22.4 \pm 0.04$ & $4.0 \pm 0.03$ \\
\hline B (probiotics) & $2.7 \pm 0.01^{* *}$ & $8.4 \pm 0.03^{\star *}$ & $31.4 \pm 0.05^{\star *}$ & $2.9 \pm 0.03^{\star *}$ \\
\hline C (enzymes) & $2.5 \pm 0.01^{* *}$ & $8.0 \pm 0.05^{* *}$ & $28.4 \pm 0.29^{* *}$ & $3.1 \pm 0.03^{* *}$ \\
\hline D (probiotics+Enzymes) & $3.0 \pm 0.03^{* *}$ & $8.7 \pm 0.02$ & $32.5 \pm 0.14^{\star *}$ & $1.4 \pm 0.05$ \\
\hline Level of significant & ${ }^{* *}$ & ${ }^{* *}$ & ${ }^{* *}$ & ${ }^{* *}$ \\
\hline
\end{tabular}

${ }^{* *}=$ Significant at $1 \%(p<0.01)$ level of probability 


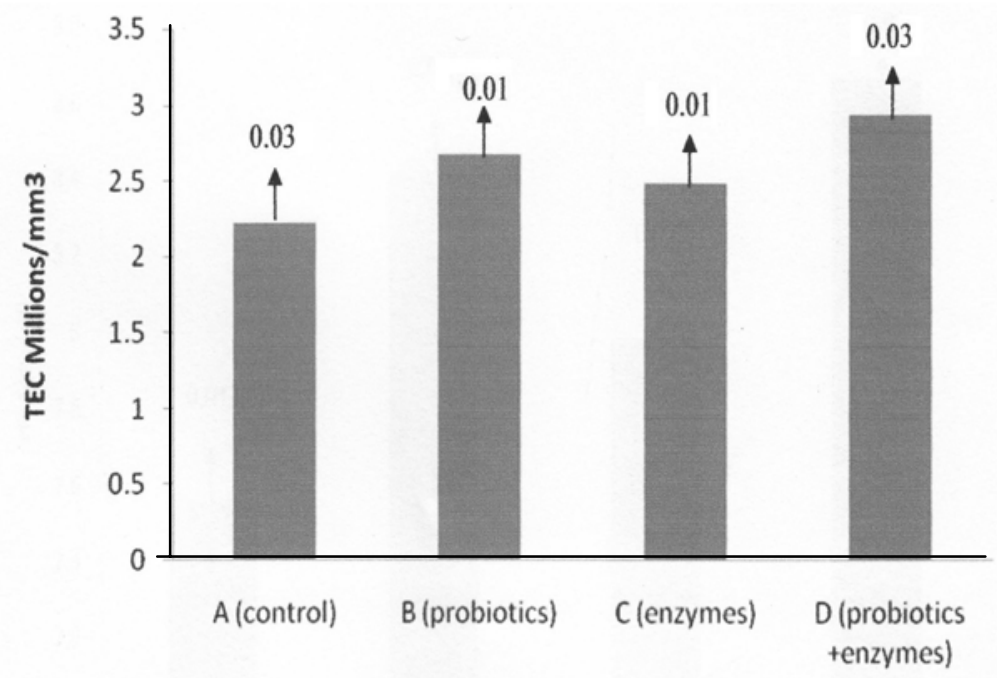

Fig. 2. Effects of probiotics and enzymes on TEC (Mean \pm SE) of different groups in broilers on $21^{\text {st }}$ day (mean $\pm S E$ ). The superscript value above bar indicates standard error

Haemoglobin content $(\mathbf{H b} \mathbf{~ g m} / \mathbf{d l})$ : Haemoglobin content in different groups of broilers is presented in the Table 4 and Fig. 3. At $21^{\text {st }}$ day (35 days of age) the values of Haemoglobin content in control group A was $7.6 \pm 0.01 \mathrm{gm} / \mathrm{dl}$ and in the treated group B was $8.4 \pm 0.03 \mathrm{gm} / \mathrm{dl}$, Group C was $8.0 \pm 0.05 \mathrm{gm} / \mathrm{dl}$ and Group D was $8.7 \pm 0.02 \mathrm{gm} / \mathrm{dl}$. The highest values of Hemoglobin content in treated Group D were 8.7 \pm 0.02 $\mathrm{gm} / \mathrm{dl}$ and lowest values of Hemoglobin content in control group A was $7.6 \pm 0.01 \mathrm{gm} / \mathrm{dl}$. All the values of treated Groups were significant $(p<0.01)$ than the control group A.

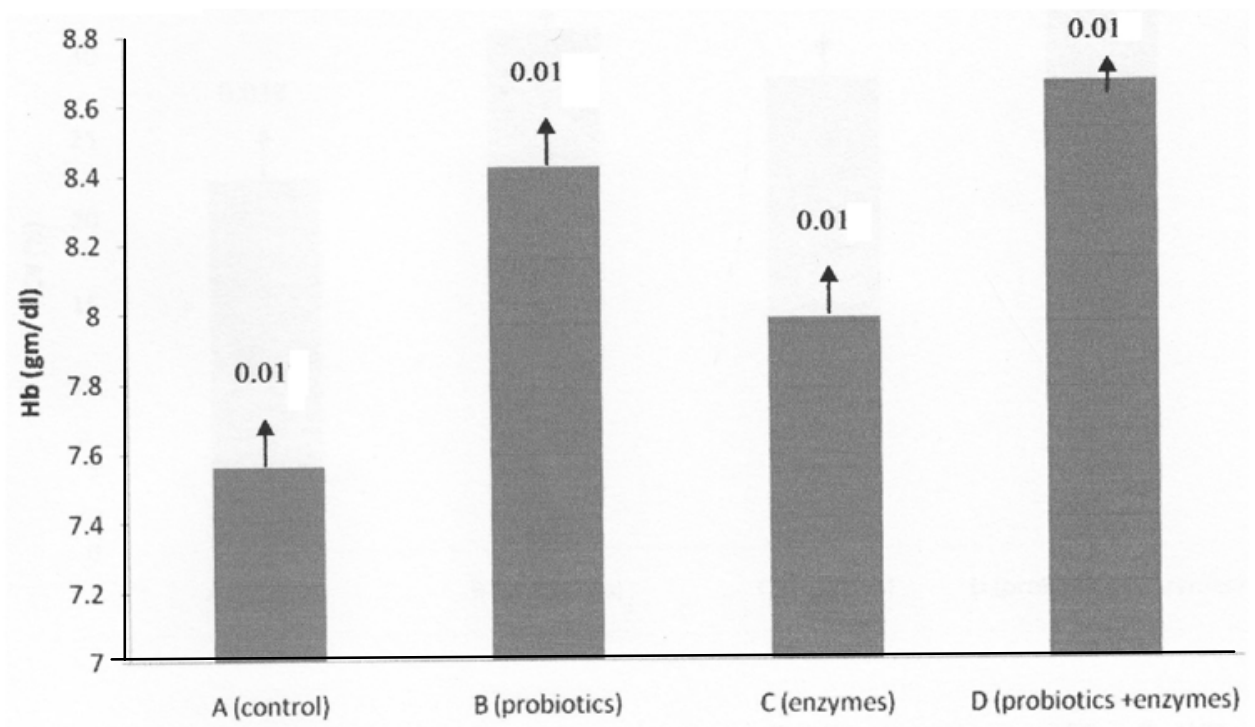

Fig. 3. Effects of probiotics and enzymes on $\mathrm{Hb}$ content (Mean $\pm \mathrm{SE}$ ) of different groups in broilers on $21^{\text {st }}$ day (mean $\pm \mathrm{SE})$. The superscript value above bar indicates standard error

Packed Cell Volume (PCV\%): Packed Cell Volume (PCV) in different groups of broilers is presented in the Table 4 and Fig. 4. At $21^{\text {st }}$ day (35 days of age) the values of PCV in control group A was $22.4 \pm 0.04 \%$ and in the treated group B was $31.4 \pm 0.05 \%$, Group $C$ was $28.4 \pm 0.3 \%$ and Group D was $32.5 \pm 0.14 \%$. The highest values of PCV in treated Group D were $32.5 \pm 0.14 \%$ and lowest values of PCV in control group A was $22.4 \pm 0.04 \%$. All the values of treated Groups were significantly $(p<0.01)$ higher than the control group A. 


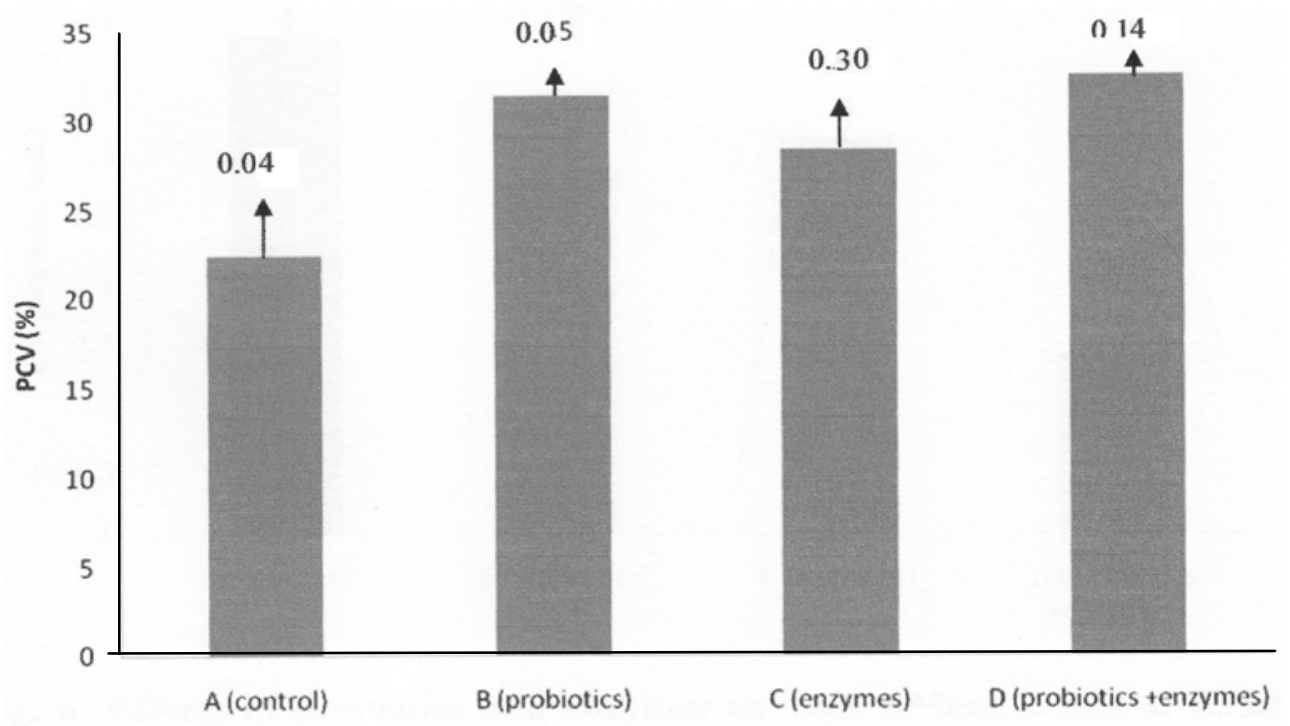

Fig 4. Effects of probiotics and enzymes on PCV (Mean \pm SE) of different groups in broilers on $21^{\text {st }}$ day (mean \pm SE). The superscript value above bar indicates standard error

Erythrocyte Sedimentation Rate (ESR $\mathbf{m m}$ ): Erythrocyte Sedimentation Rate (ESR) in different groups of broilers is presented in the Table 4 and Fig. 5 . At $21^{\text {st }}$ day ( 35 days of age) the values of ESR in control group A was $3.5 \pm 0.03 \mathrm{~mm}$ and in the treated group B was $2.9 \pm 0.03 \mathrm{~mm}$, Group $C$ was $3.1 \pm 0.03 \mathrm{~mm}$ and Group D was $1.4 \pm 0.05 \mathrm{~mm}$ in $1^{\text {st }}$ hour. The highest values of ESR in control Group A was $3.9 \pm 0.03 \mathrm{~mm}$ and lowest values of ESR in treated group A was $1.4 \pm 0.05 \mathrm{~mm}$ in $1^{\text {st }}$ hour. All the values of treated Groups were significantly $(p<0.01)$ higher than the control group $A$.

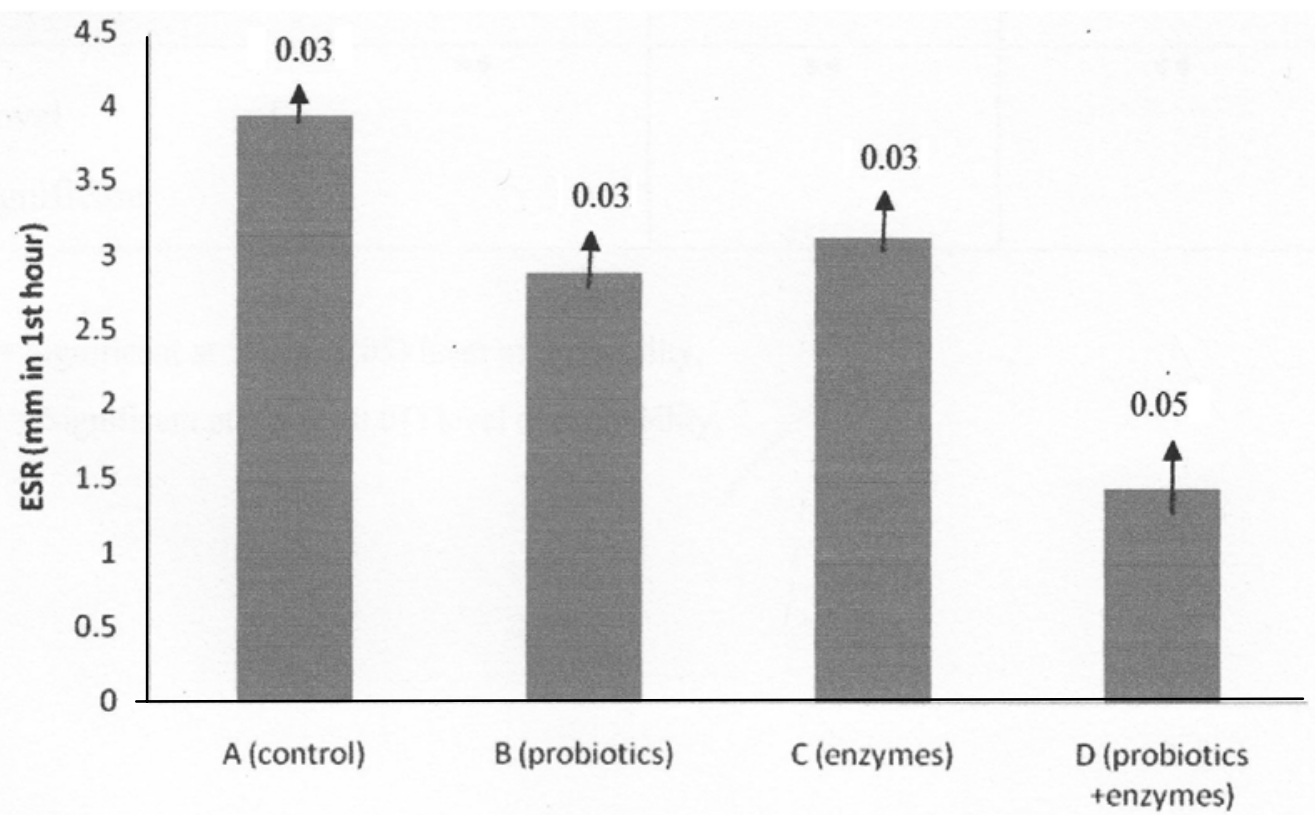

Fig. 5. Effects of probiotics and enzymes on ESR (Mean \pm SE) of different groups in broilers on $21^{\text {st }}$ day (mean $\pm S E$ ). The superscript value above bar indicates standard error 
The different values of hematological parameters were remain within normal range but statistically significant within the comparison of treated and control group. The increased level of total erythrocyte count, hemoglobin content, packed cell volume and erythrocyte sedimentation rate might be focused to the initiative effects on hematopoietic organ. The hematological parameters of presenting finding resembles to the Cowieson et al., (2006), who reported that the number of erythrocyte and other components of blood varied due to the influence of sex, environment, exercise, nutritional status and climate.

\section{Biochemical parameters (AST and ALT)}

Serum alanine aminotransaminase (AST) level (U/L): The serum AST levels in different groups of broilers are presented in Table 5 and Fig. 6 . On the final day $\left(21^{\mathrm{st}}\right)$ ( 35 days of age) the AST level was $358.3 \pm 0.60 \mathrm{U} / \mathrm{L}$ in control group $\mathrm{A}$ and treated groups the values were $356.3 \pm 0.87 \mathrm{U} / \mathrm{L}$ in group $\mathrm{B}$, $343.1 \pm 0.53 \mathrm{U} / \mathrm{L}$ in group $\mathrm{C}$ and $282.3 \pm 0.69 \mathrm{U} / \mathrm{L}$ in group $\mathrm{D}$. The highest value was in control group $A$ and lowest in treated group D. AST level was decreased in treated groups comparison to control group A but all of the treated groups the values were more or less similar and the titer values were statistically significant $(p>0.01)$ decreased than the control group $A$ but the group $D$ was decreased significantly $(p<0.05)$ than the control group A but the group $D$ was decreased significantly $(p<0.05)$ than the control group A. Kumer et al. (1976) and Pravhakaran et al. (1996) found that the ALT level decreased with the advanced age. The present study also agreed with Huff et al. (1992).

Table 5. Biocehmical parameters (Mean \pm SE) in broilers on $21^{\text {st }}$ day of experiment after treating with probiotics and enzymes

\begin{tabular}{|l|c|c|c|}
\hline Group & No. of birds & AST level (U/L) & ALT (U/L) \\
\hline A (control) & 5 & $358.3 \pm 0.60$ & $6.33 \pm 0.09$ \\
\hline B (probiotics) & 5 & $356.3 \pm 0.87^{* *}$ & $5.8 \pm 0.01^{* *}$ \\
\hline C (enzymes) & 5 & $343.1 \pm 0.53^{* *}$ & $5.0 \pm 0.01^{* *}$ \\
\hline D (probiotics + enzymes) & 5 & $282.3 \pm 0.69^{*}$ & $4.4 \pm 0.16^{* *}$ \\
\hline Level of significant & ${ }^{* *}$ & ${ }^{* *}$ & ${ }^{* *}$ \\
\hline
\end{tabular}

* $=$ Significant at $5 \%(p<0.05)$ level of probability

$* *=$ Significant at $1 \%(p<0.01)$ level of probability

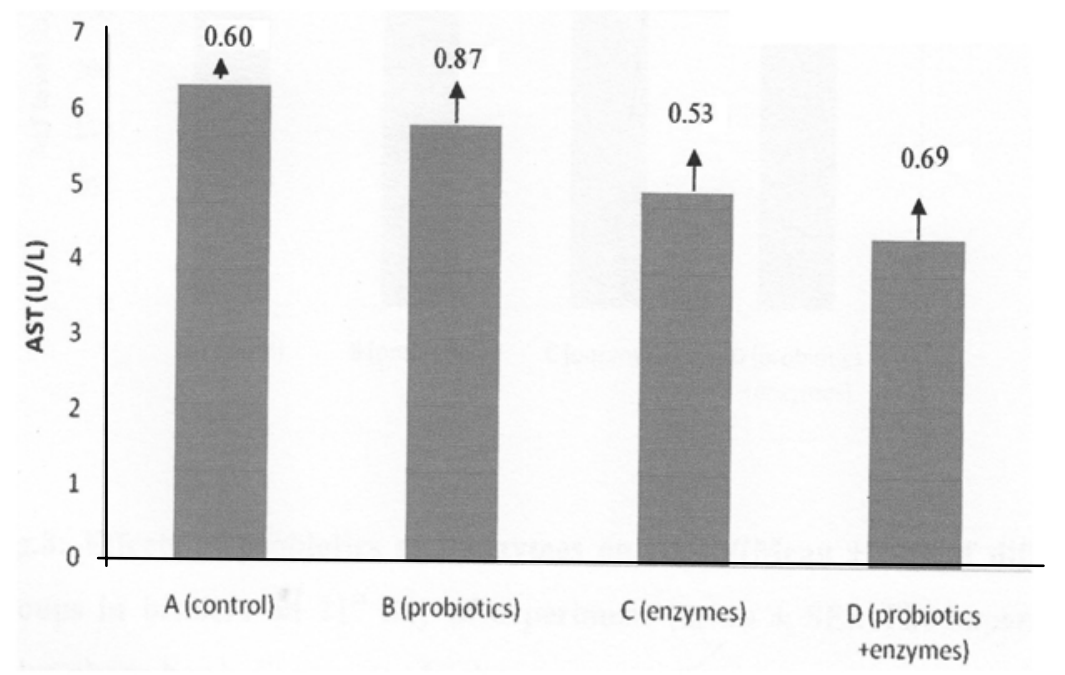

Fig. 6. Effects of probiotics and enzymes on AST (Mean \pm SE) of different groups in broilers on $21^{\text {st }}$ day (mean $\pm \mathrm{SE}$ ). The superscript value above bar indicates standard error 
Serum Serum aspertate aminotransaminase (ALT) level (U/L): The serum ALT levels in different groups of broilers are presented in Table 5 and Fig. 7 . On the final day $\left(21^{\text {st }}\right)$ of study (35 days of age) the AST level was $6.3 \pm 0.09 \mathrm{UL}$ in control group $A$ and treated groups the values were $5.8 \pm 0.01 \mathrm{U} / \mathrm{L}$ in group $\mathrm{B}, 5.0 \pm 0.01 \mathrm{U} / \mathrm{L}$ in group $\mathrm{C}$ and $4.4 \pm 0.16 \mathrm{U} / \mathrm{L}$ in group $\mathrm{D}$. The highest value was in control group $\mathrm{A}$ and lowest in treated group $D$. All the values of treated groups were statistically $(p>0.01)$ decreased than to control group A. Among the group B, C and D the ALT values were more or less similar and comparison within were statistically at $1 \%(p>0.01)$ level. Kumer and Rawat (1976) and Pravhakaran et al. (1996) found that the ALT level decreased with the advanced age. The present study also agreed with Huff et al. (1992).

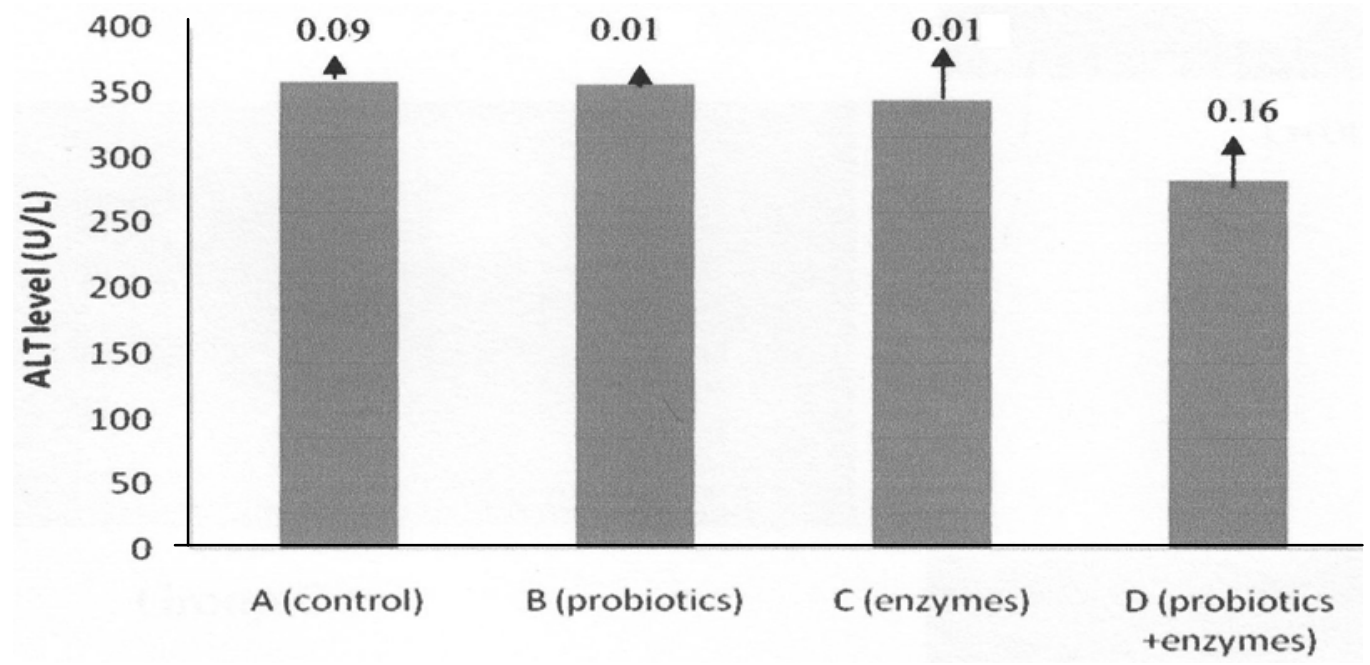

Fig. 7. Effects of probiotics and enzymes on ALT (Mean \pm SE) of different groups in broilers on $21^{\text {st }}$ day (mean $\pm S E$ ). The superscript value above bar indicates standard error

\section{References}

Ahmed, K. and Taghi, G. 2006. Effect of probiotic on performance and immunocompetence in broiler. The Journal of poultry science. 43: 296-300.

Cetih, N., Guclu, B.K. and Cetin, E. 2005. The effects of probiotic and enzyme on 4-1, some hematological and immunological parameters in turkeys. Journal of Veterinary Medicine. 52(6): 263-267.

Choct, M.. Hughes, R.J.. Trimble, R.P.. Angkanaporn, K. and Annison, G. 1995. Non-starch polysaccharide-degrading enzymes increase the performance of broiler chickens fed wheat of low apparent metabolizable energy. Journal of Nutrition. 125(3): 485-92.

Islam, M.W., Rahman, M.M., Kabir, S.M.L., Kamruzzaman, S.M., Islam, M.N. 2004. Effects of probiotics supplementation on growth performance and certain haemato-biochemical parameters in broiler chickens. Bangladesh Journal of Veterinary Medicine. 2, 39-43.

Jin, L.Z., Ho, Y.W., Abdullab, N., Jalaludin, S. 1996. Growth performance. intestinal microbial populations and serum cholesterol of broilers fed diets containing Lactobacillus cultures. International Journal of Poultry Science, 77. 1259-1265.

Kabir,-S.M.L., Rahman, M.M., Rahman, M.B. 2005. Potentiation of probiotics in promoting microbiological meat quality of broilers. International Journal of of Poultry Science, 2. 93-96.

Kim, and Hsieh, W.M. 1988. Effect of direct feed microorganism on broiler growth performance and litter ammonia level. Asian Australia Journal of animal Science, 8: 159-162.

Mohan, S., Haker, D., Pfeifer, a. and Schiffrin, E.J. 1996. Probiotics and Immune response. Clinical review and allergy Immunology, 22:287-886.

Panda, S.J.C., Sahu, B.J.C. and Rao. 1995. Urea tolerance in broiler chicken. Indian journal of Poultry Science. 63(5):54-68.

Silva, S.S. and Smithard, R.R. 2002. Effect of enzyme supplementation of a rye-based diet on xylanase activity in the small intestine of broilers and onnutrient digestibility and growth performance of the birds. British Poultry Science. 43(2): 274-82

Rosin, E.A., Blank, G. Slominski, B.A. Holley, R.A. 2007. Enzyme supplements in broiler chicken diets: in vitro and vivo effects on bacterial growth; Journal of the Science of Food and Agriculture. 87 (6): 1009-1020.

Sinnons and Sainsbury. 2001. Potential organisms to prevent diarrhea and promote digestion in farm animals. Journal of Food and Agricultural science, 49;1-13. 